medRxiv preprint doi: https://doi.org/10.1101/2021.03.19.21253938; this version posted March 27, 2021. The copyright holder for this

\title{
Visible and real sizes of the COVID-19 pandemic in Ukraine
}

\author{
Igor Nesteruk
}

Institute of Hydromechanics, National Academy of Sciences of Ukraine, Zheliabova 8/4, UA-03680 Kyiv, Ukraine

National Technical University of Ukraine "Igor Sikorsky Kyiv Polytechnic Institute", Prosp.Peremohy 37, UA03056, Kyiv, Ukraine. inesteruk@yahoo.com

\begin{abstract}
To simulate how the number of COVID-19 cases increases versus time, various data sets and different mathematical models can be used. In particular, previous simulations of the COVID-19 epidemic dynamics in Ukraine were based on smoothing of the dependence of the number of cases on time and the generalized SIR (susceptible-infected-removed) model. Since real number of cases is much higher than the official numbers of laboratory confirmed ones, there is a need to assess the degree of data incompleteness and correct the relevant forecasts. We have improved the method of estimating the unknown parameters of the generalized SIR model and calculated the optimal values of the parameters. It turned out that the real number of diseases exceeded the officially registered values by about 4.1 times at the end of 2020 in Ukraine. This fact requires a reassessment of the COVID-19 pandemic dynamics in other countries and clarification of world forecasts.
\end{abstract}

Keywords: COVID-19 pandemic, epidemic dynamics in Ukraine, mathematical modeling of infection diseases, SIR model, parameter identification, statistical methods.

\section{Introduction}

The studies of the COVID-19 pandemic dynamics are complicated by incomplete information about the number of patients (e.g., reported by WHO [1]), a very large percentage of whom are asymptomatic. In the early stages of the pandemic, there was also a lack of tests and knowledge about the specifics of the infection spread. Because of this, there are more and more evidences of COVID-19 patient appearances before the first officially-confirmed cases [2-6]. These hidden periods of the epidemics in different countries and regions were estimated in [7-11] with use of the classical SIR model [12-14] and the statistics-based method of the parameter identification developed in $[15,16]$. In particular, first COVID-19 cases probably have appeared already in August 2019 [9-11].

For Ukraine, different simulation and comparison methods were based on official accumulated NOTE: This preprint reports new research that has not been certified by peer review and should not be used to guide clinical practice. number of laboratory confirmed cases $[17,18]$ (these figures coincided with the official WHO data sets [1], but WHO stopped to provide the daily information in August 2020) and the data reported by Johns 
medRxiv preprint doi: https://doi.org/10.1101/2021.03.19.21253938; this version posted March 27, 2021. The copyright holder for this

preprint (which was not certified by peer review) is the author/funder, who has granted medRxiv a license to display the preprint in

All rights reserved. No reuse allowed without permission.

Hopkins University (JHU) [19]. In particular simple comparisons of epidemic outbreaks in Ukraine neighboring countries can be found in [20-22]. The classical SIR model was used in [7-11, 23-25]. The weakening of quarantine restrictions, changes in the social behavior and the coronavirus activity caused changes in the epidemic dynamics and corresponding parameters of models. To detect and simulate these new epidemic waves, a simple method of numerical differentiations of the smoothed number of cases and generalized SIR model were proposed and used in [11, 26-30]. In particular, nine epidemic waves in Ukraine were calculated [11, 26-30]. Since the Ukrainian national statistics does not look complete (see, e.g., the results of total staff testing in two schools and two children gardens in the Ukrainian city of Chelnytskii, [31]), there is a need to assess the extent of this incompleteness and determine the true size of the COVID-19 epidemic in Ukraine, which became the subject of this article.

\section{Data}

We will use the data set regarding the accumulated numbers of confirmed COVID-19 cases in Ukraine from national sources $[17,18]$. The corresponding numbers $V_{j}$ and moments of time $t_{j}$ (measured in days) are shown in the supplementary Table A. It must be noted that this table does not show all the COVID-19 cases occurred in Ukraine. Many infected persons are not identified, since they have no symptoms. For example, employees of two kindergartens and two schools in the Ukrainian city of Chmelnytskii were tested for antibodies to COVID-19, [31]. In total 292 people work in the surveyed institutions. Some of the staff had already fallen ill with COVID-19 or were hospitalized. Therefore, they were tested and registered accordingly. In the remaining tested 241 educators, antibodies were detected in 148. Therefore, the number of identified patients (51) in these randomly selected institutions was 3.9 times less than the actual number $(51+148)$ of COVID-19 cases. Many people know that they are ill, since they have similar symptoms as other members of families, but avoid making tests. Unfortunately, one laboratory confirmed case can correspond to several other cases which are not confirmed and displayed in the official statistics. The number of cases in Ukraine reported by COVID-19 Data Repository by the Center for Systems Science and Engineering (CSSE) at Johns Hopkins University (JHU) [19] is 2-3\% higher than the Ukrainian national statistics $[17,18]$ yields (see [30]). Nevertheless, the special simulations will demonstrate a significant incompleteness of both data sets.

\section{Generalized SIR model}

The classical SIR model for an infectious disease [12-14] was generalized in [11, 27-30] to simulate different epidemic waves. We suppose that the SIR model parameters are constant for every epidemic wave, i.e. for the time periods: $t_{i}^{*} \leq t \leq t_{i+1}^{*}, i=1,2,3, \ldots$. Than for every wave we can use the equations, similar to [12-14]: 
medRxiv preprint doi: https://doi.org/10.1101/2021.03.19.21253938; this version posted March 27, 2021. The copyright holder for this preprint (which was not certified by peer review) is the author/funder, who has granted medRxiv a license to display the preprint in perpetuity.

All rights reserved. No reuse allowed without permission.

$$
\begin{gathered}
\frac{d S}{d t}=-\alpha_{i} S I, \\
\frac{d I}{d t}=\alpha_{i} S I-\rho_{i} I, \\
\frac{d R}{d t}=\rho_{i} I .
\end{gathered}
$$

Here $S$ is the number of susceptible persons (who are sensitive to the pathogen and not protected); $I$ is the number of infected persons (who are sick and spread the infection); and $R$ is the number of removed persons (who no longer spread the infection; this number is the sum of isolated, recovered, dead, and infected people who left the region). Parameters $\alpha_{i}$ and $\rho_{i}$ are supposed to be constant for every epidemic wave.

To determine the initial conditions for the set of equations (1)-(3), let us suppose that at the beginning of every epidemic wave $t_{i}^{*}$ :

$$
\begin{gathered}
I\left(t_{i}^{*}\right)=I_{i}, R\left(t_{i}^{*}\right)=R_{i}, S\left(t_{i}^{*}\right)=N_{i}-I_{i}-R_{i} \\
N_{i}=S+I+R
\end{gathered}
$$

In $[11,27-30]$ the set of differential equations (1)-(3) was solved by introducing the function

$$
V(t)=I(t)+R(t)
$$

corresponding to the number of victims or the cumulative confirmed number of cases. For many epidemics (including the COVID-19 pandemic) we cannot observe dependencies $S(t), I(t)$ and $R(t)$ but observations of the accumulated number of cases $V_{j}$ corresponding to the moments of time $t_{j}$ provide information for direct assessments of the dependence $V(t)$. The corresponding analytical formulas for this exact solution can be written as follows:

$$
\begin{gathered}
F_{i}^{*}\left(V, N_{i}, I_{i}, R_{i}, v_{i}\right)=\alpha_{i}\left(t-t_{i}^{*}\right), \\
F_{i}^{*}=\int_{R_{i}+I_{i}}^{V} \frac{d U}{\left(N_{i}-U\right)\left[v_{i} \ln \left(N_{i}-U\right)+U-R_{i}-v_{i} \ln \left(N_{i}-R_{i}-I_{i}\right)\right]} . \\
S=N_{i}-V, \quad R=V-I
\end{gathered}
$$


medRxiv preprint doi: https://doi.org/10.1101/2021.03.19.21253938; this version posted March 27, 2021. The copyright holder for this

preprint (which was not certified by peer review) is the author/funder, who has granted medRxiv a license to display the preprint in

All rights reserved. No reuse allowed without permission.

Thus, for every set of parameters $N_{i}, I_{i}, R_{i}, v_{i}$ and a fixed value of $V$, integral (8) can be calculated and the corresponding moment of time can be determined from (7). Then functions $I(t)$ and $R(t)$ can be easily calculated with the use of formulas (9). The saturation levels $S_{i \infty} ; V_{i \infty}=N_{i}-S_{i \infty}$ (corresponding the infinite time moment) and the final day of the $i$-th epidemic wave (corresponding the moment of time when the number of persons spreading the infection will be less then 1) can be calculated with the use of equations available in [11,27-30].

\section{Parameter identification procedure}

In the case of a new epidemic, the values of its parameters are unknown and must be identified with the use of limited data sets. For the second and next epidemic waves $(i>1)$, the moments of time $t_{i}^{*}$ corresponding to their beginning are known. Therefore the exact solution (7)-(9) depend only on five parameters $-N_{i}, I_{i}, R_{i}, v_{i}, \alpha_{i}$, when the registered number of victims $V_{j}$ is the random realization of its theoretical dependence (6). If we assume, that data set $V_{j}$ is incomplete and there is a constant coefficient $\beta_{i} \geq 1$, relating the registered and real number of cases during the $i$-th epidemic wave:

$$
V\left(t_{j}\right) \cong \beta_{i} V_{j},
$$

the number of unknown parameters increases by one.

Then the values $V_{j}$, corresponding to the moments of time $t_{j}$ and relationship (10) can be used in eq. (8) in order to calculate $F_{i, j}=F_{i}^{*}\left(V_{j}, N_{i}, v_{i}, I_{i}, R_{i}, \beta_{i}\right)$ for every fixed values of $\beta_{i}, N_{i}, v_{i}, I_{i}, R_{i}$ and then to check how the registered points fit the linear dependence (7) which can be rewritten as follows:

$$
y \equiv F_{i}^{*}\left(V, N_{i}, I_{i}, R_{i}, v_{i}, \beta_{i}\right)=\gamma t+\theta ; \gamma=\alpha_{i}, \theta=-\alpha_{i} t_{i}^{*}
$$

We can calculate the parameters $\gamma$ and $\theta$, by treating the values $y_{j} \equiv F_{i}^{*}\left(V_{i}, N_{i}, I_{i}, R_{i}, v_{i}, \beta_{i}\right)$ and corresponding time moments $t_{j}$ as random variables. Then we can use the observations of the accumulated number of cases and the linear regression in order to calculate the coefficients $\hat{\gamma}$ and $\hat{\theta}$ of the regression line

$$
\widehat{y}=\hat{\gamma} t+\hat{\theta}
$$

using the standard formulas (see, e.g., [32]). Values $\hat{\gamma}$ and $\hat{\theta}$ can be treated as statistics-based estimations for parameters $\gamma$ and $\theta$ from relationships (11). 
medRxiv preprint doi: https://doi.org/10.1101/2021.03.19.21253938; this version posted March 27, 2021. The copyright holder for this

preprint (which was not certified by peer review) is the author/funder, who has granted medRxiv a license to display the preprint in

All rights reserved. No reuse allowed without permission.

The reliability of the method can be checked by calculating the correlation coefficients $r_{i}$ (see e.g., [13]) for every epidemic wave and checking how close are their values is to unity. We can use also the F-test [13] for the null hypothesis that says that the proposed linear relationship (11) fits the data set. Similar approach was used in $[7-11,15,16,23-30,33,34]$. To calculate the optimal values of parameters $\beta_{i}, N_{i}, v_{i}, I_{i}, R_{i}$, we have to find the maximum of the correlation coefficient for the linear dependence (11).

The exact solution (7)-(9) allows avoiding numerical solutions of differential equations (1)-(3) and significantly reduces the time spent on calculations. A new algorithm [11, 29, 30] allows estimating the optimal values of SIR parameters for the $i$-th epidemic wave directly (without simulations of the previous waves). To reduce the number of unknown parameters, we can use the relationship $V_{i}=I_{i}+R_{i}$ which follows from (6) and (10). To estimate the value $V_{i}$, we can use the smoothed accumulated number of cases [11, 26-30]

$$
\bar{V}_{i}=\frac{1}{7} \sum_{j=i-3}^{j=i+3} V_{j}
$$

and the relationship $V_{i} \approx \beta_{i} \bar{V}_{i}$ following from (10) ( $i$ corresponds to the moment of time $t_{i}^{*}$ ). One more relationship

$$
I_{i}=\left.\frac{1}{\alpha_{i}\left(N_{i}-V_{i}\right)} \frac{d V}{d t}\right|_{t=t_{i}^{*}}
$$

can be obtained with the use of (5) and formula

$$
\frac{d V}{d t}=\alpha_{i} S I
$$

(following from (2) and (3)). To estimate the average number of new cases $d V / d t$ at the moment of time $t_{i}^{*}$ in eq. (14), we can use the numerical differentiation of (13):

$$
\left.\frac{d \bar{V}}{d t}\right|_{t=t_{i}} \approx \frac{1}{2}\left(\bar{V}_{i+1}-\bar{V}_{i-1}\right)
$$

and relationship (10). Thus we have only three independent parameters $\beta_{i}, N_{i}$ and $v_{i}$. To calculate the value of parameter $\alpha_{i}$, some iterations can be used (see details in [11]).

\section{Results}

The optimal values of parameters and other characteristics of the ninth COVID-19 pandemic wave in Ukraine are listed in Table 1 for two cases. For SIR simulations we have used the same period of time $T_{c}$ : December 11-24, 2020 and corresponding values of $V_{j}$ and $t_{j}$ from Table A. In the first case 
medRxiv preprint doi: https://doi.org/10.1101/2021.03.19.21253938; this version posted March 27, 2021. The copyright holder for this

preprint (which was not certified by peer review) is the author/funder, who has granted medRxiv a license to display the preprint in

All rights reserved. No reuse allowed without permission.

we assumed that the numbers of registered cases coincide with the real one $\left(\beta_{9}=1\right)$. A similar SIR simulation of the 9th epidemic wave in Ukraine has already been reported in [30], but now we have managed to find a new (larger in value) maximum of the correlation coefficient.

The last column of Table 1 illustrate the results of SIR simulations with the non-prescribed value of $\beta_{9}$. The maximum of the correlation coefficient was achieved at $\beta_{9}=4.1024$. This result testifies that the main part of the epidemic in Ukraine is invisible. At the end of 2020 the real numbers of COVID-19 cases probably were more than 4 times higher than registered ones. The real final size of the ninth epidemic wave $V_{9 \infty}$ is expected to be around 6 million. Unfortunately, we cannot wait for the end of the pandemic before the summer of 2022 (if vaccinations will not change this sad trend).

Knowing the optimal values of parameters, the corresponding SIR curves can be easily calculated with the use of exact solution (7)-(9) and compared with the pandemic observations after $T_{c}$. The results are shown in Figure by different colors. Black and blue lines and markers correspond to the case $\beta_{9}=4.1024$. The solid black line shows complete accumulated number of cases (visible and invisible); the dashed line represents the complete number of infected persons multiplied by 5 , i.e. $I(t) x 5$; dotted black line represent the derivative $d V / d t$ (which is an estimation of the real daily number of new cases) calculated with the use of (15) and multiplied by 100 . The red dotted line shows the dependence $V(t)$ for the case $\beta_{9}=1$ (assuming that all the cases are registered). The red "circles", "triangles", and "stars" correspond to the accumulated numbers of cases registered during period of time taken for SIR simulations $T_{c}$, before $T_{c}$, and after $T_{c}$, respectively (taken from Table A). The blue dotted line represents dependence $I(t) / \beta_{9}$. The blue crosses show the estimation of the derivative (16) multiplied by $100 \beta_{9}$.

\section{Discussion}

According to the results of our study, we can only say that in the case of suitability of the generalized SIR model, the value $\beta_{9}=4.1024$ and other optimal values of its parameters (given in the last column of Table 1) are the most reliable (provide the maximum value of the correlation coefficient). Therefore, we used additional methods to verify the calculations and showed some results in Fig. The blue dotted line represents dependence $I(t) / \beta_{9}$ which must be close to the registered number of cases (red markers). The coincidence is very good. Significant deviations began to appear only in March 2021, which can be explained by the beginning of the next (tenth) epidemic wave in Ukraine. The blue crosses show the estimation of the real daily number of new cases (derivative (16) multiplied by $100 \beta_{9}$ ) and have to be close to the black dotted line. Significant deviations began to appear only in mid-February 2021, which can be explained canceling the lockdown on January 24, 
medRxiv preprint doi: https://doi.org/10.1101/2021.03.19.21253938; this version posted March 27, 2021. The copyright holder for this preprint (which was not certified by peer review) is the author/funder, who has granted medRxiv a license to display the preprint in

All rights reserved. No reuse allowed without permission.

2021. May be the beginning of the tenth epidemic wave is connected also with the starting the lessons at schools and universities and mutations of the coronavirus.

\begin{tabular}{|c|c|c|}
\hline Characteristics & $\begin{array}{c}9^{\text {th }} \text { epidemic wave, } \\
i=9, \\
\beta_{i}=1 \text { (without } \\
\text { optimization) }\end{array}$ & $\begin{array}{c}9^{\text {th }} \text { epidemic wave, } \\
i=9 \\
\beta_{i}=4.1024\end{array}$ \\
\hline$I_{i}$ & $148,390.742887927$ & $668,766.512528977$ \\
\hline$R_{i}$ & $732,364.542826359$ & $2,944,443.97158531$ \\
\hline$N_{i}$ & $2,960,000$ & $12,307,200$ \\
\hline$v_{i}$ & $2,275,096.81932990$ & 9626720.00517470 \\
\hline$\alpha_{i}$ & $3.48830042313868 \mathrm{e}-08$ & $7.59399763733452 \mathrm{e}-09$ \\
\hline$\rho_{i}$ & 0.0793622119754996 & 0.0731052889745776 \\
\hline $1 / \rho_{i}$ & 12.6004552432172 & 13.6789008569236 \\
\hline$r_{i}$ & 0,998201733486790 & 0.998205208046402 \\
\hline$S_{i \infty}$ & $1,530,454$ & $6,372,870$ \\
\hline$V_{i \infty}$ & $1,429,546$ & $5,934,330$ \\
\hline $\begin{array}{l}\text { Final day of the } \\
\text { epidemic wave }\end{array}$ & April 17, 2022 & July 24, 2022 \\
\hline
\end{tabular}

Table 1. Calculated optimal values of SIR parameters and other characteristics of the ninth COVID-19 pandemic wave in Ukraine.

The calculated coefficient of epidemic visibility $\beta_{9}=4.1024$ correlates with the results of testing employees of two kindergartens and two schools in the Ukrainian city of Chmelnytskii [31] which revealed the value 3.9. Probably that large discrepancy between registered and actual number of cases occurred not only in Ukraine. For example, total testing in Slovakia (65.5\% of population was tested on October 31 - November 1,2020 ) revealed a number of previously undetected cases, equal to about $1 \%$ of the population [35]. On November 7 next $24 \%$ of the population was tested and found $0.63 \%$ of 
medRxiv preprint doi: https://doi.org/10.1101/2021.03.19.21253938; this version posted March 27, 2021. The copyright holder for this

preprint (which was not certified by peer review) is the author/funder, who has granted medRxiv a license to display the preprint in perpetuity.

All rights reserved. No reuse allowed without permission.

those infected [36]. According to the WHO report at the end of October, the number of detected cases in Slovakia was also approximately $1 \%$ of population [1].

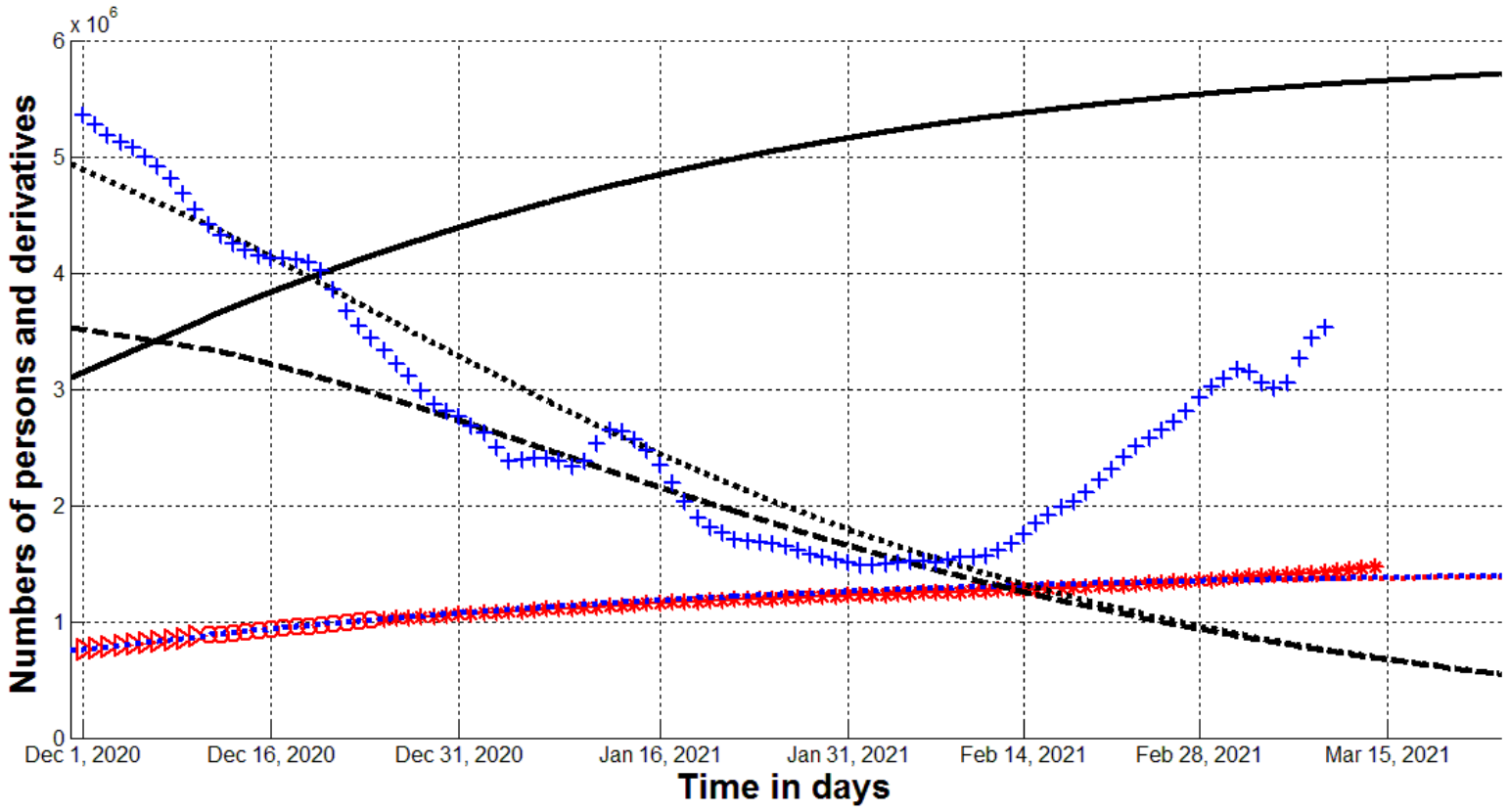

Figure. Visible (red) and real (black) COVID-19 epidemic dynamics in Ukraine.

Red markers show accumulated numbers of cases $V_{j}$ from Table A. "Circles" correspond to the accumulated numbers of cases taken for calculations (during period of time $T_{c}$ ); "triangles" - numbers of cases before $T_{c}$; "stars" - number of cases after $T_{c}$. Blue and black colors correspond to the case $\beta_{9}=4.1024$; the blue "crosses" show derivative (16) multiplied by $100 \beta_{9}$; the blue dotted line represents dependence $I(t) / \beta_{9}$. Numbers of victims $V(t)=I(t)+R(t)$ - black solid lines; numbers of infected and spreading $I(t)$ multiplied by 5 - dashed; derivatives $d V / d t$ (eq. (15)) multiplied by $100-$ dotted. The red dotted line represents dependence $I(t) / \beta_{9}$ for the case $\beta_{9}=1$.

Many authors are and will be trying to predict the COVID-19 pandemic dynamics in many countries and regions [7-11, 16, 23-30, 37-102]. The results of this study indicate that reliable estimates of its dynamics require consideration of incomplete data and constant changes of the conditions (quarantine restrictions, social distancing, coronavirus mutations, etc.).

\section{References}

1. World Health Organization. "Coronavirus disease (COVID-2019) situation reports". https://www.who.int/emergencies/diseases/novel-coronavirus-2019/situation-reports/. Retrieved Oct. 3, 2020 .

2. Li, Q., Guan, X., Wu, P., et al. "Early transmission dynamics in Wuhan, China, of novel coronavirus-infected pneumonia." The New England journal of medicine, 2020 Jan. 29. doi:10.1056/NEJMoa2001316.

3. https://www.scmp.com/news/china/society/article/3076334/coronavirus-strange-pneumonia-seenlombardy-november-leading 
medRxiv preprint doi: https://doi.org/10.1101/2021.03.19.21253938; this version posted March 27, 2021. The copyright holder for this preprint (which was not certified by peer review) is the author/funder, who has granted medRxiv a license to display the preprint in All rights reserved. No reuse allowed without permission.

4. F.-X. Lescure et al. Clinical and virological data of the first cases of COVID-19 in Europe: a case series. www.thelancet.com/infection Published online March 27, 2020 https://doi.org/10.1016/S1473-3099(20)30200-0

5. Frankfurter Allgemeine. https://m.faz.net/aktuell/sport/mehr-sport/militaerweltspiele-2019-inwuhan-damals-schon-corona-faelle-16758894.html

6. Weinberger DM et al. Estimating the early death toll of COVID-19 in the United States. [Preprint.] MEDRXIV, 2020 Apr. https://doi.org/10.1101/2020.04.15.2006643

7. Nesteruk I. Long-term predictions for COVID-19 pandemic dynamics in Ukraine, Austria and Italy [Preprint.] MEDRXIV, 2020 Apr. DOI: 10.13140/RG.2.2.31170.53448

8. Nesteruk I. SIR-simulation of Corona pandemic dynamics in Europe. [Preprint.] MEDRXIV, 2020 Apr. DOI: https://medrxiv.org/cgi/content/short/2020.04.22.20075135v1

9. Nesteruk I. Simulations and predictions of COVID-19 pandemic with the use of SIR model. Innov Biosyst Bioeng, 2020, vol. 4, no. 2, 110-121, doi: 10.20535/ibb.2020.4.2.204274. http://ibb.kpi.ua/article/view/204274

10. Nesteruk I. Hidden periods, duration and final size of COVID-19 pandemic. Preprint. MedRxiv. May 10, 2020. https://www.medrxiv.org/content/what-unrefereedpreprinthttps://medrxiv.org/cgi/content/short/2020.05.10.20097147v1

11. Nesteruk I. COVID19 pandemic dynamics. Springer Nature, 2021, DOI: 10.1007/978-981-33-64165

12. Kermack WO, McKendrick AG. A Contribution to the mathematical theory of epidemics. J Royal Stat Soc Ser A. 1927;115:700-21.

13. Murray JD. Mathematical Biology I/II. New York: Springer; 2002.

14. Langemann D, Nesteruk I, Prestin J. Comparison of mathematical models for the dynamics of the Chernivtsi children disease. Mathematics in Computers and Simulation. 2016;123:68-79. DOI: 10.1016/j.matcom.2016.01.003

15. Nesteruk I. Statistics based models for the dynamics of Chernivtsi children disease. Naukovi Visti NTUU KPI. 2017;5:26-34. DOI: 10.20535/1810-0546.2017.5.108577

16. Nesteruk I. Statistics-based predictions of coronavirus epidemic spreading in mainland China. Innov Biosyst Bioeng. 2020; 4(1):13-18. DOI: 10.20535/ibb.2020.4.1.195074.

17. https://index.minfin.com.ua/ua/reference/coronavirus/ukraine/

18. https://www.kmu.gov.ua/

19. COVID-19 Data Repository by the Center for Systems Science and Engineering (CSSE) at Johns Hopkins University (JHU). https://github.com/owid/covid-19-data/tree/master/public/data

20. Nesteruk, I. "Comparison of the coronavirus pandemic dynamics in Ukraine and neighboring countries” [Preprint.] ResearchGate. 2020 Mar. doi: 10.13140/RG.2.2.31170.53448 
medRxiv preprint doi: https://doi.org/10.1101/2021.03.19.21253938; this version posted March 27, 2021. The copyright holder for this preprint (which was not certified by peer review) is the author/funder, who has granted medRxiv a license to display the preprint in All rights reserved. No reuse allowed without permission.

21. Nesteruk, I., Kydybyn, I., Demelmair, G. Corona pandemic global stabilization? [Preprint.] ResearchGate. 2020 April. doi: 10.13140/RG.2.2.21570.32961

https://www.researchgate.net/publication/340917471_Corona_pandemic_global_stabilization

22. Nesteruk, I., Kydybyn, I., Demelmair, G. GLOBAL STABILIZATION TRENDS OF COVID-19 PANDEMIC. KPI Science News, 2020, No. 2, pp. 55-62. DOI: 10.20535/kpi-sn.2020.2.205124

23. Nesteruk I. Як довго українці сидітимуть на карантині? How long will the Ukrainians stay in quarantine? (in Ukrainian) [Preprint.] ResearchGate. 2020 Apr. doi: 10.13140/RG.2.2.15732.71046

24. Nesteruk I. Динаміка COVID-19 епідемії в Україні та Києві після покращання тестування. COVID-19 epidemic dynamics in Ukraine and Kyiv after testing has improved (In Ukrainian).

[Preprint.] ResearchGate. 2020 Apr. doi: 10.13140/RG.2.2.36705.86885

25. Nesteruk I. Статистика пандемії COVID-19 в Україні та світі COVID-19 pandemic statistics in Ukraine and world. (In Ukrainian). ResearchGate. 2020 May doi:10.13140/RG.2.2.30999.39842 https://www.researchgate.net/publication/341542317_Statistika_pandemii_COVID19_v_Ukraini_ta_sviti_COVID-19_pandemic_statistics_in_Ukraine_and_world

26. Nesteruk I. Coronasummer in Ukraine and Austria. [Preprint.] ResearchGate. 2020 June. DOI: 10.13140/RG.2.2.32738.56002

27. Nesteruk I. Waves of COVID-19 pandemic. Detection and SIR simulations. MedRxiv. 2020 Aug. doi: https://doi.org/10.1101/2020.08.03.20167098

https://www.medrxiv.org/content/10.1101/2020.08.03.20167098v1

28. Nesteruk I. Нові хвилі пандемії COVID-19 в Україні. New waves of COVID-19 pandemic in Ukraine. (In Ukrainian). [Preprint.] ResearchGate. 2020 Aug. DOI:10.13140/RG.2.2.26172.26244 https://www.researchgate.net/publication/343979510_Novi_hvili_pandemii_COVID19_v_Ukraini_New_waves_of_COVID-19_pandemic_in_Ukraine

29. Nesteruk I. COVID-19 pandemic dynamics in Ukraine after September 1, 2020. MedRxiv. Posted December 22, 2020. Doi: https://doi.org/10.1101/2020.12.21.20248627

30. Nesteruk I. Estimates of the COVID-19 pandemic dynamics in Ukraine based on two data sets. MedRxiv. Posted February 20, 2021. Doi: https://doi.org/10.1101/2021.02.18.21252000

31. https://podillyanews.com/2020/12/17/u-shkolah-hmelnytskogo-provely-eksperyment-ztestuvannyam-na-covid-19/

32. Draper NR, Smith H. Applied regression analysis. 3rd ed. John Wiley; 1998.

33. Gazzola M., Argentina M. \& L. Mahadevan. Scaling macroscopic aquatic locomotion. Nature Physics volume 10, pages 758-761 (2014).

34. I. Nesteruk, "Maximal speed of underwater locomotion", Innov Biosyst Bioeng, 2019, vol. 3, no. 3, pp. 152-167. Doi: https://doi.org/10.20535/ibb.2019.3.3.177976

35. https://edition.cnn.com/2020/11/02/europe/slovakia-mass-coronavirus-test-intl/index.html

36. https://www.voanews.com/covid-19-pandemic/slovakias-second-round-coronavirus-tests-drawslarge-crowds 
medRxiv preprint doi: https://doi.org/10.1101/2021.03.19.21253938; this version posted March 27, 2021. The copyright holder for this preprint (which was not certified by peer review) is the author/funder, who has granted medRxiv a license to display the preprint in perpetuity.

All rights reserved. No reuse allowed without permission.

37. Joseph T Wu, Kathy Leung, Gabriel M Leung .Nowcasting and Forecasting the Potential Domestic and International Spread of the 2019-nCoV Outbreak Originating in Wuhan, China: A Modelling Study. Lancet 2020 Jan 31. DOI: 10.1016/S0140-6736(20)30260-9

38. Shi Zhao, Qianyin Lin, Jinjun Ran, Salihu S Musa, Guangpu Yang, Weiming Wang, Yijun Lou, Daozhou Gao, and others. Preliminary estimation of the basic reproduction number of novel coronavirus (2019-nCoV) in China, from 2019 to 2020: A data-driven analysis in the early phase of the outbreak. International Journal of Infectious Diseases. Published online: January 30, 2020.

DOI:https://doi.org/10.1016/j.ijid.2020.01.050

39. Byass, P. Eco-epidemiological assessment of the COVID-19 epidemic in China, January-Februry 2020. medRxiv 2020, doi:10.1101/2020.03.29.20046565.

40. Tang, B., Bragazzi, N. L., Li, Q., et al. "An updated estimation of the risk of transmission of the novel coronavirus (2019-nCov).” Infectious disease modelling, vol. 5, pp. 248-255. 2020 Feb. 11. doi:10.1016/j.idm.2020.02.001.

41. Ying Liu, Gayle AA, Wilder-Smith A, Rocklöv J. The reproductive number of COVID-19 is higher compared to SARS coronavirus. Jurnal of Travel Medicine, Volume 27, Issue 2, March 2020, taaa021, https://doi.org/10.1093/jtm/taaa021

42. Kucharski AJ. et al. Early dynamics of transmission and control of COVID-19: a mathematical modelling study. TheLancet Infectious Diseases (2020)

Published:March 11, 2020DOI:https://doi.org/10.1016/S1473-3099(20)30144-4

43. Batista, M. "Estimation of the final size of the COVID-19 epidemic." [Preprint.] medRxiv. 2020 Feb. 28. doi:10.1101/2020.02.16.20023606.

44. J. Dehning et al. Inferring COVID-19 spreading rates and potential change points for case number forecasts. Preprint, ArXiv:2004.01105(2020).

45. Chen Y, Cheng J, Jiang Y, Liu K. A time delay dynamical model for outbreak of 2019-nCoV and the parameter identification. ArXiv:2002.00418; 2020.

46. Peng L, Yang W, Zhang D, Zhuge C,Hong L. Epidemic analysis of COVID-19 in China by dynamical modeling. ArXiv:2002.06563;2020.

47. Chang SL, Harding N, Zachreson C, Cliff OM, Prokopenko M. Modelling transmission and control of the COVID-19 pandemic in Australia. ArXiv:2003.10218;2020.

48. Maier BF, Brockmann D. Effective containment explains sub-exponential growth in confirmed cases of recent COVID-19 out break in mainland China. ArXiv:2002.07572;2020.

49. Song PX, Wang L, Zhou Y, He J, Zhu B, Wang F, et al. An epidemiological forecast model and software assessing interventions on COVID-19 epidemic in China. MedRxiv. 2020;

50. Chinazzi M, Davis JT, Ajelli M, Gioannini C, Litvinova M, Merler S, et al. The effect of travel restrictions on the spread of the 2019 novel coronavirus (COVID-19) outbreak. Science. 2020; 368(6489):395-400. https://doi.org/10.1126/science.aba9757PMID:32144116

51. Zhang Y,Jiang B,Yuan J, Tao Y. The impact of social distancing and epicenter lockdown on the COVID-19 epidemic in mainland China: A data-driven SEIQR model study. MedRxiv. 2020; 
medRxiv preprint doi: https://doi.org/10.1101/2021.03.19.21253938; this version posted March 27, 2021. The copyright holder for this preprint (which was not certified by peer review) is the author/funder, who has granted medRxiv a license to display the preprint in All rights reserved. No reuse allowed without permission.

52. Noureddine Benlagha. Modeling the Declared New Cases of COVID-19 Trend Using Advanced Statistical Approaches. [Preprint.] ResearchGate.

March 2020. DOI: 10.6084/m9.figshare. 12052638

53. Chang SL, Harding N, Zachreson C, Cliff OM, Prokopenko M. Modelling transmission and control of the COVID-19 pandemic in Australia. ArXiv:2003.10218;2020.

54. Pongkaew Udomsamuthirun et al. The reproductive index from SEIR model of Covid-19 epidemic in Asean. [Preprint.] MEDRXIV, 2020 Apr.

DOI: https://doi.org/10.1101/2020.04.24.20078287

55. Pereira IG et al. Forecasting Covid-19 Dynamics in Brazil: A Data Driven Approach.

Int. J. Environ. Res. Public Health 2020, 17(14), 5115; https://doi.org/10.3390/ijerph17145115

56. Linka K., Peirlinck M., Kuhl E. The reproduction number of COVID-19 and its correlation with public health interventions. [Preprint.] MEDRXIV, 2020. DOI:10.1101/2020.05.01.20088047

57. Distante, C.; Gadelha Pereira, I.; Garcia Goncalves, L.M.; Piscitelli, P.; Miani, A. Forecasting Covid-19 Outbreak Progression in Italian Regions: A model based on neural network training from Chinese data. medRxiv 2020.

58. Hamzah, F.; Binti, A.; Lau, C.; Nazri, H.; Ligot, D.V.; Lee, G.; Tan, C.L. CoronaTracker: Worldwide COVID-19 Outbreak Data Analysis and Prediction. Bull. World Health Organ. 2020, 1, 32.

59. Fanelli, D.; Piazza, F. Analysis and forecast of COVID-19 spreading in China, Italy and France. Chaos Solitons Fractals 2020, 134, 109761.

60. Webb, G.F.; Magal, P.; Liu, Z.; Seydi, O. A model to predict COVID-19 epidemics with applications to South Korea, Italy, and Spain. medRxiv 2020.

61. Bastos, S.B.; Cajueiro, D.O. Modeling and forecasting the early evolution of the Covid-19 pandemic in Brazil. arXiv 2020, arXiv:2003.14288.

62. Grant, A. Dynamics of COVID-19 epidemics: SEIR models underestimate peak infection rates and overestimate epidemic duration. medRxiv 2020.

63. Loli Piccolomiini, E.; Zama, F. Monitoring Italian COVID-19 spread by an adaptive SEIRD model. medRxiv 2020.

64. Baerwolff, G.K. A Contribution to the Mathematical Modeling of the Corona/COVID-19 Pandemic. medRxiv 2020.

65. Distante, C.; Piscitelli, P.; Miani, A. Covid-19 Outbreak Progression in Italian Regions: Approaching the Peak by the End of March in Northern Italy and First Week of April in Southern Italy. Int. J. Environ. Res. Public Health 2020, 17, 3025.

66. te Vrugt, M.; Bickmann, J.; Wittkowski, R. Effects of social distancing and isolation on epidemic spreading: A dynamical density functional theory model. arXiv 2020, arXiv:2003.13967.

67. Yang, Z.; Zeng, Z.; Wang, K.; Wong, S.S.; Liang, W.; Zanin, M.; Liu, P.; Cao, X.; Gao, Z.; Mai, Z.; et al. Modified SEIR and AI prediction of the epidemics trend of COVID-19 in China under public health interventions. J. Thorac. Dis. 2020, 12, 165. 
medRxiv preprint doi: https://doi.org/10.1101/2021.03.19.21253938; this version posted March 27, 2021. The copyright holder for this preprint (which was not certified by peer review) is the author/funder, who has granted medRxiv a license to display the preprint in perpetuity.

All rights reserved. No reuse allowed without permission.

68. Roda, W.C.; Varughese, M.B.; Han, D.; Li, M.Y. Why is it difficult to accurately predict the COVID-19 epidemic? Infect. Dis. Model. 2020, 5, 271-281.

69. Otunuga, O.M.; Ogunsolu, M.O. Qualitative analysis of a stochastic SEITR epidemic model with multiple stages of infection and treatment. Infect. Dis. Model. 2020, 5, 61-90.

70. K Chatterjee et al. Healthcare impact of COVID-19 epidemic in India: A stochastic mathematical model. Medical Journal Armed Forces India. Volume 76, Issue 2, April 2020, Pages 147-155

71. I Ciufolini, A Paolozzi. Mathematical prediction of the time evolution of the COVID-19 pandemic in Italy by a Gauss error function and Monte Carlo simulations. Eur. Phys. J. Plus (2020) 135: 355 https://doi.org/10.1140/epjp/s13360-020-00383-y

72. S Annas et al. Stability analysis and numerical simulation of SEIR model for pandemic COVID-19 spread in Indonesia. Chaos, Solitons \& Fractals

Volume 139, October 2020, 110072 https://doi.org/10.1016/j.chaos.2020.110072

73. RP Yadav, R Verma A numerical simulation of fractional order mathematical modeling of COVID-19 disease in case of Wuhan China. Chaos, Solitons \& Fractals. Volume 140, November 2020, 110124

https://doi.org/10.1016/j.chaos.2020.110124

74. KY Ng, MM Gui. COVID-19: Development of a robust mathematical model and simulation package with consideration for ageing population and time delay for control action and resusceptibility. Physica D: Nonlinear Phenomena.Volume 411, October 2020, 132599

https://doi.org/10.1016/j.physd.2020.132599Get rights and content

75. B.Ivorra, M.R.Ferrández, M.Vela-Pérez, A.M.Ramos. Mathematical modeling of the spread of the coronavirus disease 2019 (COVID-19) taking into account the undetected infections. The case of China. Communications in Nonlinear Science and Numerical Simulation, Volume 88, September 2020, 105303, https://doi.org/10.1016/j.cnsns.2020.105303

76. Nguyen HuyTuan, Hakimeh Mohammadi, Shahram Rezapour. A mathematical model for COVID19 transmission by using the Caputo fractional derivative. Chaos, Solitons \& Fractals. 2020, 110107. https://doi.org/10.1016/j.chaos.2020.110107

77. Musalula Sinkala, Panji Nkhoma, Mildred Zulu, Doris Kafita, Rabecca Tembo, Victor Daka. The COVID-19 Pandemic in Africa: Predictions using the SIR Model. medRxiv 2020.06.01.20118893; doi: https://doi.org/10.1101/2020.06.01.2011889

78. Komi Agbokou1, Kossi Gneyou1, Kokou Tcharie. Investigation on the temporal evolution of the covid'19pandemic: prediction for Togo. Open Jornal of mathematical sciencies. 2020, 4, 273-279; doi:10.30538/oms2020.0118https://pisrt.org/psr-press/journals/oms

79. Gergő Pintér,Imre Felde,Amir Mosavi, Richard Gloaguen. COVID-19 Pandemic Prediction for Hungary; A Hybrid Machine Learning Approach. Mathematics 2020, 8, 890; doi:10.3390/math8060890www.mdpi.com/journal/mathematics

80. Cody Carroll et al.Time Dynamics of COVID-19. medRxiv 2020.05.21.20109405; doi: https://doi.org/10.1101/2020.05.21.2010940

81. Khaled M Furati, Ibrahim O. Sarumi, Abdul Q.M. Khaliq. Memory-Dependent Model for the Dynamics of COVID-19 Pandemic. medRxiv 2020.06.26.20141242; doi:

https://doi.org/10.1101/2020.06.26.20141242 
medRxiv preprint doi: https://doi.org/10.1101/2021.03.19.21253938; this version posted March 27, 2021. The copyright holder for this preprint (which was not certified by peer review) is the author/funder, who has granted medRxiv a license to display the preprint in

All rights reserved. No reuse allowed without permission.

82. Jurgen Bosch, Austin Wilson, Karthik O'Neil, Pater A Zimmerman. COVID-19 Predict Predicting Pandemic Trends. medRxiv 2020.09.09.20191593; doi:

https://doi.org/10.1101/2020.09.09.20191593

83. Ali Asad, Siddharth Srivastava, Mahendra K. Verma. Evolution of COVID-19 Pandemic in India. medRxiv 2020.07.01.20143925; doi: https://doi.org/10.1101/2020.07.01.20143925

84. Nawel Aries, Houdayfa Ounis. Mathematical Modeling of COVID-19 Pandemic in the African Continent. medRxiv 2020.10.10.20210427;

doi: https://doi.org/10.1101/2020.10.10.20210427

85. Felix Guenther, Andreas Bender, Katharina Katz, Helmut Kuechenhoff, Michael Hoehle. Nowcasting the COVID-19 Pandemic in Bavaria. medRxiv 2020.06.26.20140210; doi: https://doi.org/10.1101/2020.06.26.20140210

86. Wan Yang, Jaimie Shaff, Jeffrey Shaman. COVID-19 Transmission Dynamics and Effectiveness of Public Health Interventions in New York City during the 2020 Spring Pandemic Wave. medRxiv 2020.09.08.20190710; doi: https://doi.org/10.1101/2020.09.08.20190710

87. Ronald Dickman. A SEIR-like model with a time-dependent contagion factor describes the dynamics of the Covid-19 pandemic. medRxiv 2020.08.06.20169557; doi:

https://doi.org/10.1101/2020.08.06.20169557

88. Lakshmi Rani Kundu, Most. Zannatul Ferdous, Ummay Soumayia Islam, Marjia Sultana. Forecasting the spread of COVID-19 pandemic in Bangladesh using ARIMA model. medRxiv 2020.10.22.20217414; doi: https://doi.org/10.1101/2020.10.22.20217414

89. Diego Carvalho, Rafael Barbastefano, Dayse Pastore, Maria Clara Lippi.

A novel predictive mathematical model for COVID-19 pandemic with quarantine, contagion dynamics, and environmentally mediated transmission.

medRxiv 2020.07.27.20163063;

doi: https://doi.org/10.1101/2020.07.27.20163063

90. Md. Haider Ali Biswas, M. S. Khatun, A. K. Paul, M. R. Khatun, M. A. Islam, S. A. Samad, U. Ghosh. Modeling the Effective Control Strategy for Transmission Dynamics of Global Pandemic COVID-19. medRxiv 2020.04.22.20076158; doi: https://doi.org/10.1101/2020.04.22.20076158

91. Elinor Aviv-Sharon, Asaph Aharoni. Forecasting COVID-19 pandemic Severity in Asia. medRxiv 2020.05.15.20102640;

doi: https://doi.org/10.1101/2020.05.15.20102640

92. Nayana Bannur, Harsh Maheshwari, Sansiddh Jain, Shreyas Shetty, Srujana Merugu, Alpan Raval. Adaptive COVID-19 Forecasting via Bayesian Optimization. medRxiv 2020.10.19.20215293; doi: https://doi.org/10.1101/2020.10.19.2021529

93. Sewanou H. Honfo, Beaugard H. Taboe, Romain Glele Kakai. Modeling COVID-19 dynamics in the sixteen West African countries. medRxiv 2020.09.04.20188532; doi: https://doi.org/10.1101/2020.09.04.20188532

94. Piotr T. Chruściel, Sebastian J. Szybka. Universal properties of the dynamics of the Covid-19 pandemics. medRxiv 2020.08.24.20181214;

doi: https://doi.org/10.1101/2020.08.24.20181214 
medRxiv preprint doi: https://doi.org/10.1101/2021.03.19.21253938; this version posted March 27, 2021. The copyright holder for this preprint (which was not certified by peer review) is the author/funder, who has granted medRxiv a license to display the preprint in All rights reserved. No reuse allowed without permission.

95. BRAHMATHEJA REDDY MALI REDDY, ANUJ SINGH, PRADEEP SRIVASTAVA. COVID19 TRANSMISSION DYNAMICS IN INDIA WITH EXTENDED SEIR MODEL. medRxiv 2020.08.15.20175703; doi: https://doi.org/10.1101/2020.08.15.20175703

96. Jianping Huang, Xiaoyue Liu, Li Zhang, Kehu Yang, Yaolong Chen, Zhongwei Huang, Chuwei Liu, Xinbo Lian, Danfeng Wang. The amplified second outbreaks of global COVID-19 pandemic. medRxiv 2020.07.15.20154161; doi: https://doi.org/10.1101/2020.07.15.2015416

97. Gyan Bhanot, Charles DeLisi. Analysis of Covid-19 Data for Eight European Countries and the United Kingdom Using a Simplified SIR Model. medRxiv 2020.05.26.20114058; doi: https://doi.org/10.1101/2020.05.26.20114058

98. Mahmoud A. Ibrahim, Amenah Al-Najafi. Modeling, Control, and Prediction of the Spread of COVID-19 Using Compartmental, Logistic, and Gauss Models: A Case Study in Iraq and Egypt . Processes2020,8, 1400; doi:10.3390/pr8111400

99. Gaetano Perone. Comparison of ARIMA, ETS, NNAR and hybrid models to forecast the second wave of COVID-19 hospitalizations in Italy (HEDG-WP 20/18, University of York). Preprint. http://www.york.ac.uk/economics/postgrad/herc/hedg/wps/

100. Átila Madureira Bueno, Cristiane M. Batistela, Diego Paolo Ferruzzo Correa, J.R.C. Piqueira. SIRSi compartmental model for COVID-19 pandemic with immunity loss. Chaos Solitons \& Fractals, Oct 2020. DOI: 10.1016/j.chaos.2020.110388

101. Ahmed E. Fahmya, Mohammed M. El-desoukya, Ahmed S.A. Mohamed. Epidemic Analysis of COVID-19 in Egypt, Qatar and Saudi Arabia using the Generalized SEIR Model. MedRxiv. Posted August 22, 2020. Doi: https://doi.org/10.1101/2020.08.19.20178129

102. Ryad Ghanam, Edward L. Boone, Abdel-Salam G. Abdel-Salam. SEIRD MODEL FOR QATAR COVID-19 OUTBREAK: A CASE STUDY. Posted 26 May 2020. arXiv:2005.12777v1

\section{Acknowledgements}

The author is grateful to Oleksii Rodionov for his help in collecting and processing data. 
medRxiv preprint doi: https://doi.org/10.1101/2021.03.19.21253938; this version posted March 27, 2021. The copyright holder for this preprint (which was not certified by peer review) is the author/funder, who has granted medRxiv a license to display the preprint in

All rights reserved. No reuse allowed without permission.

\section{Supplementary materials}

\begin{tabular}{|c|c|c|c|c|c|c|c|}
\hline $\begin{array}{c}\text { Day in } \\
\text { Decem- } \\
\text { ber } \\
2020 \\
t_{j}\end{array}$ & $\begin{array}{c}\text { Number } \\
\text { of cases, } \\
V_{j}\end{array}$ & $\begin{array}{c}\text { Day in } \\
\text { Janu- } \\
\text { ary } \\
2021\end{array}$ & $\begin{array}{c}\text { Number of } \\
\text { cases, } \\
V_{j}\end{array}$ & $\begin{array}{c}\text { Day in } \\
\text { Febru- } \\
\text { ary } \\
2021\end{array}$ & $\begin{array}{c}\text { Number of } \\
\text { cases, } \\
V_{j}\end{array}$ & $\begin{array}{l}\text { Day in } \\
\text { March } \\
2021\end{array}$ & $\begin{array}{c}\text { Number of } \\
\text { cases, } \\
V_{j}\end{array}$ \\
\hline 1 & 758264 & 1 & 1069517 & 1 & 1223879 & 1 & 1357470 \\
\hline 2 & 772760 & 2 & 1074093 & 2 & 1227164 & 2 & 1364705 \\
\hline 3 & 787891 & 3 & 1078251 & 3 & 1232246 & 3 & 1374762 \\
\hline 4 & 801716 & 4 & 1083585 & 4 & 1237169 & 4 & 1384917 \\
\hline 5 & 813306 & 5 & 1090496 & 5 & 1241479 & 5 & 1394061 \\
\hline 6 & 821947 & 6 & 1099493 & 6 & 1244849 & 6 & 1401228 \\
\hline 7 & 832758 & 7 & 1105169 & 7 & 1246990 & 7 & 1406800 \\
\hline 8 & 845343 & 8 & 1110015 & 8 & 1249646 & 8 & 1410061 \\
\hline 9 & 858714 & 9 & 1115026 & 9 & 1253055 & 9 & 1416438 \\
\hline 10 & 872228 & 10 & 1119314 & 10 & 1258094 & 10 & 1425522 \\
\hline 11 & 885039 & 11 & 1124430 & 11 & 1262867 & 11 & 1438468 \\
\hline 12 & 894215 & 12 & 1130839 & 12 & 1268049 & 12 & 1451744 \\
\hline 13 & 900666 & 13 & 1138764 & 13 & 1271143 & 13 & 1460756 \\
\hline 14 & 909082 & 14 & 1146963 & 14 & 1273475 & 14 & 1467548 \\
\hline 15 & 919704 & 15 & 1154692 & 15 & 1276618 & - & - \\
\hline 16 & 931751 & 16 & 1160682 & 16 & 1280904 & - & - \\
\hline 17 & 944381 & 17 & 1163716 & 17 & 1287141 & - & - \\
\hline 18 & 956123 & 18 & 1167655 & 18 & 1293672 & - & - \\
\hline 19 & 964448 & 19 & 1172038 & 19 & 1299967 & - & - \\
\hline 20 & 970993 & 20 & 1177621 & 20 & 1304456 & - & - \\
\hline 21 & 979506 & 21 & 1182969 & 21 & 1307662 & - & - \\
\hline 22 & 989642 & 22 & 1187897 & 22 & 1311844 & - & - \\
\hline 23 & 1001132 & 23 & 1191812 & 23 & 1317694 & - & - \\
\hline 24 & 1012167 & 24 & 1194328 & 24 & 1325841 & - & - \\
\hline 25 & 1019876 & 25 & 1197107 & 25 & 1333844 & - & - \\
\hline 26 & 1025989 & 26 & 1200883 & 26 & 1342016 & - & - \\
\hline 27 & 1030374 & 27 & 1206412 & 27 & 1347849 & - & - \\
\hline 28 & 1037362 & 28 & 1211593 & 28 & 1352134 & - & - \\
\hline 29 & 1045348 & 29 & 1216278 & - & - & - & - \\
\hline 30 & 1055047 & 30 & 1219455 & - & - & - & - \\
\hline 31 & 1064479 & 31 & 1221485 & - & - & - & - \\
\hline
\end{tabular}

Table A. Cumulative numbers of laboratory confirmed Covid-19 cases in Ukraine $V_{j}$ according to the national statistics, $[7,8]$. 